Review

\title{
Unmanned Helicopters
}

\author{
${ }^{1}$ Relly Victoria Petrescu, ${ }^{2}$ Raffaella Aversa, ${ }^{3}$ Bilal Akash, ${ }^{2}$ Antonio Apicella and \\ ${ }^{1}$ Florian Ion Tiberiu Petrescu \\ ${ }^{I}$ ARoTMM-IFToMM, Bucharest Polytechnic University, Bucharest, (CE), Romania \\ ${ }^{2}$ Advanced Material Lab, Department of Architecture and Industrial Design, \\ Second University of Naples, 81031 Aversa (CE), Italy \\ ${ }^{3}$ Dean of School of Graduate Studies and Research, American University of Ras Al Khaimah, UAE
}

Article history

Received: 18-10-2017

Revised: $27-10-2017$

Accepted: 06-11-2017

Corresponding Author: Florian Ion Tiberiu Petrescu ARoTMM-IFToMM, Bucharest Polytechnic University, Bucharest, (CE), Romania E-mail: scipub02@gmail.com
Abstract: Airbus, the European aerospace giant is working on the transport solutions that will be used in the cities of the future. In their research laboratories, technicians are working on the creation of a network of flying and $100 \%$ autonomous vehicles. An innovation that could well contribute to preparing the transport of cities of the future. One of the most famous unmanned helicopters is Northrop Grumman MQ-8 Fire Scout, a pilotless helicopter developed by Northrop Grumman specifically for use by the United States Armed Forces. The project called Scout Fire was designed to provide recognition, situational awareness, support for aerial fire and support for accurate focusing of ground, air and sea forces. Airbus imagines a flying taxis driven by a pilot at first. This first step allowed a faster implementation which would test and create this new market. Then, flying taxis would become more and more autonomous as the regulations evolve. The fare may eventually cost the price of a current taxi fare for each of the passengers. The race will be faster, more respectful of the environment and certainly more fun! Probably at first many people will be afraid to climb aboard such vehicles, but in time they will get used to the idea and will try their use. Just to get rid of people's fears of using such vehicles faster, they will initially be fitted with a pilot who will test the vehicle for a while and talk to passengers trying to encourage them. We are initially talking about pilot flying taxis, so they are first implemented. But then the flights will be absolutely alone, without a pilot and people will go to such a taxi in a station and then they will ask for the route and the desired destination or perhaps only the destination and the taxi will take them he alone automatically at the required destination. Perhaps such a project would seem at first glance a beautiful dream, fantastic even though unrealistic. Still, let's not forget that today we already have unmanned helicopters, operated from a job that follows them. Today we already have many airplanes and unmanned flying boats flying successfully. At first, they only transported goods and objects, usually military, but then they also began to transport people, combat crews. Implementation has been stepped up and controlled, so projects of this kind are not doomed to failure. Today we all know that this project has succeeded and is already operational anywhere in the world. Today we are already starting to build it and tomorrow it will become a reality. Technologies have advanced far enough to develop such a bold project. A city specially designed to carry a city-based fly-trip project has the advantage that all buildings, roads, fixed or moving obstacles are built right from the start as it should, avoiding the many unknowns that seem easier to overcome in the initial pilot flight, but can be a further problem when the pilot leaves the cabin of the aircraft and will do it alone. Of course, it's not just an automated pilot, but a whole unmanned flight control concept that is constantly controlled even if the routes are designed to be automatically recorded.

Keywords: Unmanned Helicopters, Pilotless Helicopter, Modern Flight, Flight Quality, High Safety, Some Special Aircraf, Helicopters, Spacecraft Propulsion, US Army, Northrop Grumman 


\section{Introduction}

Airbus develops unmanned flying taxis project for cities of the future. Airbus, the European aerospace giant is working on the transport solutions that will be used in the cities of the future. In their research laboratories, technicians are working on the creation of a network of flying and $100 \%$ autonomous vehicles. An innovation that could well contribute to preparing the transport of cities of the future (Fig. 1).

Developing a network of autonomous flying vehicles (Fig. 2) capable of carrying several passengers to different parts of the city may seem crazy or at least very futuristic. However, it is taken seriously by the aerospace group whose Airbus Helicopter branch is working on an unmanned flying taxi project with the Silicon Valley group's innovation department. Their project is described in the internal magazine Forum of the month of August: to design a vehicle with "revolutionary design that could soon become reality without having to wait too much for regulatory changes".

The City Airbus project consists of designing a vehicle that would run on electricity, with several propellers that would make it look like both a small helicopter and a drone. Its use would be quite simple since users would book their autonomous and flying taxi from their Smartphone, they would go on a dedicated platform, the ZenHUB located at specific locations; airports, train stations, ... the whole system is secured thanks to a cyber-secure network (Fig. 3).

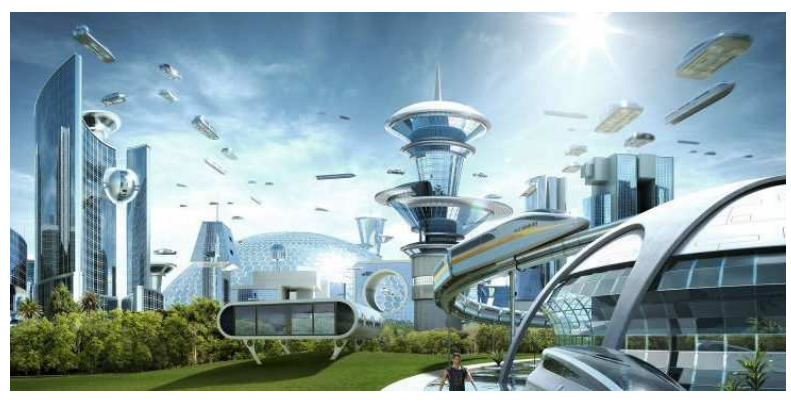

Fig. 1: Cities of the future with unmanned flying taxis

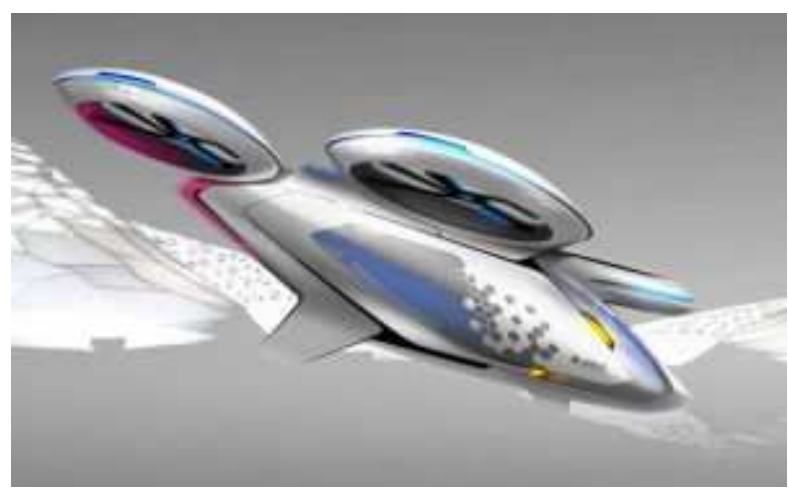

Fig. 2: Developing a network of autonomous flying vehicles

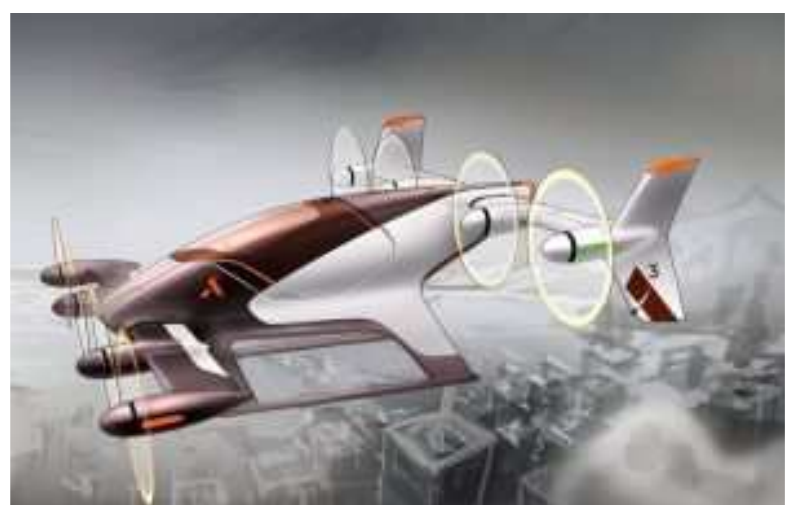

Fig. 3: A flying taxi from

Airbus imagines a flying taxis driven by a pilot at first. This first step allowed a faster implementation which would test and create this new market. Then, flying taxis would become more and more autonomous as the regulations evolve.

The fare may eventually cost the price of a current taxi fare for each of the passengers. The race will be faster, more respectful of the environment and certainly more fun!

Probably at first many people will be afraid to climb aboard such vehicles, but in time they will get used to the idea and will try their use. Just to get rid of people's fears of using such vehicles faster, they will initially be fitted with a pilot who will test the vehicle for a while and talk to passengers trying to encourage them. We are initially talking about pilot flying taxis, so they are first implemented. But then the flights will be absolutely alone, without a pilot and people will go to such a taxi in a station and then they will ask for the route and the desired destination or perhaps only the destination and the taxi will take them he alone automatically at the required destination. Perhaps such a project would seem at first glance a beautiful dream, fantastic even though unrealistic. Still, let's not forget that today we already have unmanned helicopters, operated from a job that follows them. Today we already have many airplanes and unmanned flying boats flying successfully. At first, they only transported goods and objects, usually military, but then they also began to transport people, combat crews. Implementation has been stepped up and controlled, so projects of this kind are not doomed to failure. Today we all know that this project has succeeded and is already operational anywhere in the world. If it could have been operated on combat theaters and anywhere in the world, the more successful it is in a pilot city where flight control is easier, the routes known and virtually unimportant because the city will be properly designed, convenient to the flight autonomous and unmanned. Practically, the chances of success of such a project are now very high. It takes some time, a lot of work, seriousness and, of course, a finance for a such project. 


\section{Materials and Methods}

Before the time man could at the most dream of such a project. Today we are already starting to build it and tomorrow it will become a reality. Technologies have advanced far enough to develop such a bold project. A city specially designed to carry a city-based fly-trip project has the advantage that all buildings, roads, fixed or moving obstacles are built right from the start as it should, avoiding the many unknowns that seem easier to overcome in the initial pilot flight, but can be a further problem when the pilot leaves the cabin of the aircraft and will do it alone. Of course, it's not just an automated pilot, but a whole unmanned flight control concept that is constantly controlled even if the routes are designed to be automatically recorded. Possible obstacles can be avoided today even if they were not foreseen because there are sensors of sight at any time and time, specialized sensors that have already been successfully tested over a long time on autonomous robots, autonomous vehicles and even flying machines. Even so, it is normal for the flight to be controlled also by electromagnetic waves permanently by an automatic station located in a well built and positioned centrally in the new planned city. Not only satellites and communication antennas but also specialized radars will be used for this purpose. Now it is easier to understand the importance of this project being carried out in a new, completely new city built from scratch, according to the needs of the project.

Normally such a flight could be carried over buildings because the specially constructed city would not generally have other ships with which the city taxi would collide. On take-off and landing when the flying taxi will have to fly between buildings, besides the fact that for every route used there is a program with all the free flight lanes, it is possible to use taxi sensors as well as on buildings, thus that any taxi can feel the distance from time to any building or object so they can fly quietly among them regardless of height. This could even create flight color among buildings, avoiding large flight heights, detours and especially spaces that could interfere with any other flying object.

Over these signaling systems coming from buildings, other sensors can be added to allow the flying machine to easily identify all buildings and obstacles long before meeting them.

In addition, there will be some mobile radar capable of intuition of the free route and avoiding all the obstacles in time. Not to mention again that the city is built specifically for autonomous and unmanned taxis and buildings can be conveniently targeted, thus creating routes and optimum flight color, which will anyway already be memorized and implemented within a program Initial flight on each flying taxi.

Imagine now that besides city taxis there will be cars without a driver for people who are not rushing and who want to reach their destination with a classic taxi, but which will not be so classic either because it does not he will have a driver. You simply climb into a taxi car in a specially arranged station, end the final destination with or without the desired route and the car leaves immediately to the destination of the traveler (travelers), using only the public roads of the city.

There could also be mixed, hybrid vehicles that go on a regular taxi and in some possible hindrances or traffic jamming, they can take their flight as an autonomous helicopter to cross the crowded area. Otherwise, such situations will be rarer in such a specially designed city because traffic will be greatly de-congested by the use of flying taxis by more and more courageous citizens.

Obviously, if the city is a big one, it will be possible to use metro in this city. The subway was the only means of transport that managed to disengage the big crowded cities from the $50 \mathrm{~s}$ to the $60 \mathrm{~s}$. Like Paris, London, New York and many other metropolitan cities have been able to diminish the huge queues from the stops and to rebuild urban traffic again. If we now also take flight taxis for the same main purpose, streamline urban traffic at any hour and time, obviously we only have to win. However, for such a courageous and ambitious project to succeed from the start, it is a good idea to introduce the first project of its kind into a newly built city, specially built for the purpose of accepting taxis.

Flying taxis, dozens of autonomous cars, the City Airbus project plunges us into the greatest Science Fiction movies. By taking up the challenge of working and imagining the means of transport that will be used by the people of the cities of the future, Airbus is trying to get a head start, even if, without a doubt, its competitors also have plans in the boxes.

Because if nowadays to be able to circulate in the large conglomerations is a permanent challenge, what will it be in the years to come? The problem of transport in the big cities is growing and will continue to be so since by 2030 $60 \%$ of the world's population will live in big cities, which represents a growth of $10 \%$ compared to today.

City Airbus, the flying and autonomous taxi of Airbus could be a part of the solution to the mobility problem that future planners will have to solve.

A simple option that could be used in the future in any of the already existing cities would be low-altitude flying taxis, possibly with easy-to-control color over water courses.

If there are no cabs, but it is difficult to change the course when the main water in the city does not correspond to the route desired by the taxi customer, it would be easier to implement a small flying taxi to follow a major water course in the city and when it is not possible, it can still leave the area flying either at low altitude or at a higher height, not guiding the flow of water. 


\section{Results}

One of the best-known unmanned helicopters is the Northrop Grumman MQ-8 Fire Scout, a pilotless helicopter developed by Northrop Grumman specifically for use by the United States Armed Forces. The Scout Fire project has been designed to ensure recognition, situation awareness, aircraft support and support for precise focusing of land, air and sea forces. The first version of the RQ-8A is based on the Schweizer 330 and the improved version of the MQ-8B was derived from the Schweizer 333. The much larger version of the MQ8C Fire Scout is based on the Bell 407.

When the American ship withdrew its pioneers from the RQ-2 service, it began looking for a second-generation UAV. Marine requirements specify a Vertical Take-off and take-off model (VTOL), which has a payload of $90 \mathrm{~kg}$ $(200 \mathrm{lb})$, can travel at least 200 kilometers, has a power of three stations at an altitude of 20,000 m); and especially capable of landing on a windscreen of $46 \mathrm{~km} / \mathrm{h}(29 \mathrm{mph})$. UAV was required to perform a minimum of 190 flight hours before planned maintenance.

Three finalists have been nominated for the final of the competition to designate a single VTOL-UAV or VTUAV, Bell, Sikorsky and Teledyne Ryan and Schweizer. The Ryan-Schweizer UAV was named a winner in the spring of 2000. The RQ-8A Fire Scout, as it was called, was derived from the three-passenger 330SP helicopter equipped with a new fuselage, a new combustion of the system, sensors and UAV.

The original prototype of the fire shield was piloted in the initial tests and flew autonomously for the first time in January 2000. The Rolls-Royce 250-C20 swirl engine made JP-8 and JP-5 fuel jets with a point of attraction larger, safe for storage and onboard use).

The fire shield was equipped with a set of ball probes containing infrared photoelectric cameras as well as a laser search appliance. It had to be controlled by a data link derived from the Global Hawk RQ-4 UW from Northwest Grumman, operating on a line of vision of up to $280 \mathrm{~km}$. The control system can be installed on a ship or can be easily attached and transported to a US Marine Humvee service.

Although the progress of the project was considered satisfactory, Marine decided that Shield of Fire did not meet its requirements successfully and immediately reduced production funding in December 2001.

The development program continued, however and Northrop Grumman presented a number of improvements to the configuration all. As it turned out, the US military was very interested in offering a contract for seven enhanced rating RQ-8B at the end of 2003. Only in 2006 was the MQ-8B redrawn.

The MQ-8B comes with a four-rotor main rotor, unlike the larger rotor with a diameter of more than $3 \mathrm{~m}$ RQ-8A, to achieve better balancing to reduce noise and improve the lifting capacity and performance of the machine during the flight.

The four-axis rotor has already been evaluated on the Fire Scout prototypes. They increased the gross take-off weight by 230 kilograms to 1,430 kilograms, with a payload of 320 kilograms for short-range missions. The MQ-8B had a length of $7.30 \mathrm{~m}$, a width of $1.9 \mathrm{~m}$ and a height of $2.96 \mathrm{~m}$.

The MQ-8B was equipped with winged fins that serve both an aerodynamic purpose and a weapon delivery location.

Weapons to be shipped include Hellfire missiles, Viper Strike-guided weapons and especially carts carrying a $70 \mathrm{~K}$ Advanced Weapon System (APKWS), which the army saw as ideal for the modern battlefield. The army was also interested in using the fire badge to carry up to $91 \mathrm{~kg}$ of emergency supplies.

The MQ-8B Module has been modified to allow quick change of load configuration.

The actual sensor configuration for a day/night turret with a laser target indicator will remain an option. Useful tasks for alternate sensors include a TSAR with Motion Targeting (MTI) capabilities, a multispectral sensor, a SIGINT module, the Target Mining Detection System (ASTAMIDS) and a common Tactical Data Link (TCDL) it is desirable that the Fire Shield also function as an element of an integrated ground sensor network (Northrop Grumman MQ-8 Fire Scout, From Wikipedia; Petrescu and Petrescu, 2013a; 2013b; 2013c; 2012a; 2012b, 2011; Petrescu, 2009), Fig. 4.

Always materials used to build aircraft have been a priority (Aversa et al., 2017a; 2017b; 2017c; 2017d; 2017e; 2016a; 2016b; 2016c; 2016d; 2016e; 2016f; 2016g; 2016h; 2016i; 2016j; 2016k; 2016l; 2016m; 2016n; 2016o; Mirsayar et al., 2017). But at that time, there were no possibilities of today in creating of materials.

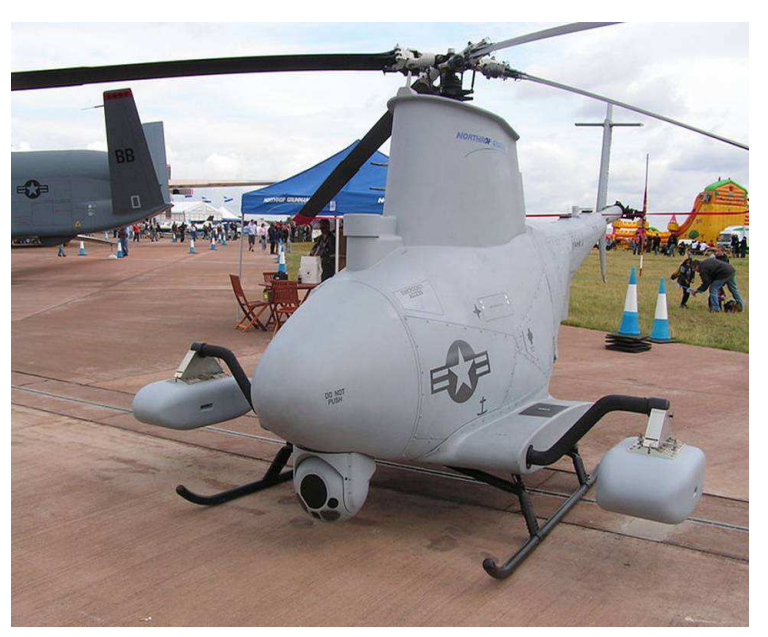

Fig. 4: An MQ-8B fire scout displayed at the royal international air tattoo, RAF fair ford, gloucestershire, England, July 2007 
In April 2006, flight test production was initiated directly at the Unmanned Systems plant in Northman Grumman, Moss Point, Mississippi. The first flight of the MQ-8B took place on December 18, 2006, at Patuxent Naval River Air Station. On this occasion, the army's interest in this program revived, with the $8 \mathrm{MQ}-$ 8B ship away from it. Only in January 2010, the army ceased to be involved in the fire shield, arguing that the RQ-7 Shadow UAV could respond to the army's needs at the time. In 2009, however, Marina approved initial production, even if it was low.

Thus, the MQ-8B finished aboard the Captain Airborne crew and was deployed with an SH-60B HSL/HSM detachment or an MH-60S HSC detachment. But with the planned addition of radar, AIS and weapons, the MQ-8B will provide much more capability to the SH-60B crew. This will give air detachments greater flexibility in fulfilling the mission requirements and lead to the release of human-powered aircraft and the automation of fully robotic missions.

This enabled the development of unmanned helicopter systems and on September 23, 2011, Air Systems Commander awarded Northrop Grumman a \$ 17 million contract to equip the MQ-8B with $70 \mathrm{~mm}$ advanced laser missiles. By August 2013, the MQ-8B has completed 11 of the 12 APWKS versions.

On December 30, 2012, Marina issued an emergency command to install the RDR-1700 maritime surveillance radar on nine MQ-8B. The RDR-1700 is a synthetic Xband radar that is in a modified raid mounted on the underside of the 360-degree UAV and its helicopter. The detailed area is $25 \mathrm{~km}$, with a maximum radius of $80 \mathrm{~km}$. It is important that the RDR-1700 can see through clouds and sandstorms and can perform field mapping or weather detection and can immediately track 20 air or surface targets, determining range, speed and target speed. In January 2013, Marina awarded a \$ 33 million telecom contract for the RDR-1700B + radar, designated AN / ZPY-4 (V) 1. This time, the radar offers the ability to search and track an extended area beyond the horizon, can instantly track up to 200 targets and work on surfaces, map the territory, detect an emergency and meteorological beacons that complement FLIR systems. The demonstration took place on an MQ-8B on May 7, 2014.

Thus, with unmanned and unmanned helicopters, the automated, robotic, electronic, mechatronized war was born.It follows that in 2017 , the MQ-8B will receive a mine detection sensor for use in coastal waters called the Coastal Combat Exploration and Analysis (COBRA). COBRA is designed to detect naval mines at a safe distance from a coastal combat ship operating in coastal waters and also has the ability to locate submarines by acoustic detection if they are on or near the surface. COBRA replaces the custom EO/IR sensor of the Fire Shield (Northrop Grumman Fire Scout performs first autonomous naval landing of a UAV", US Navy), Fig. 5.

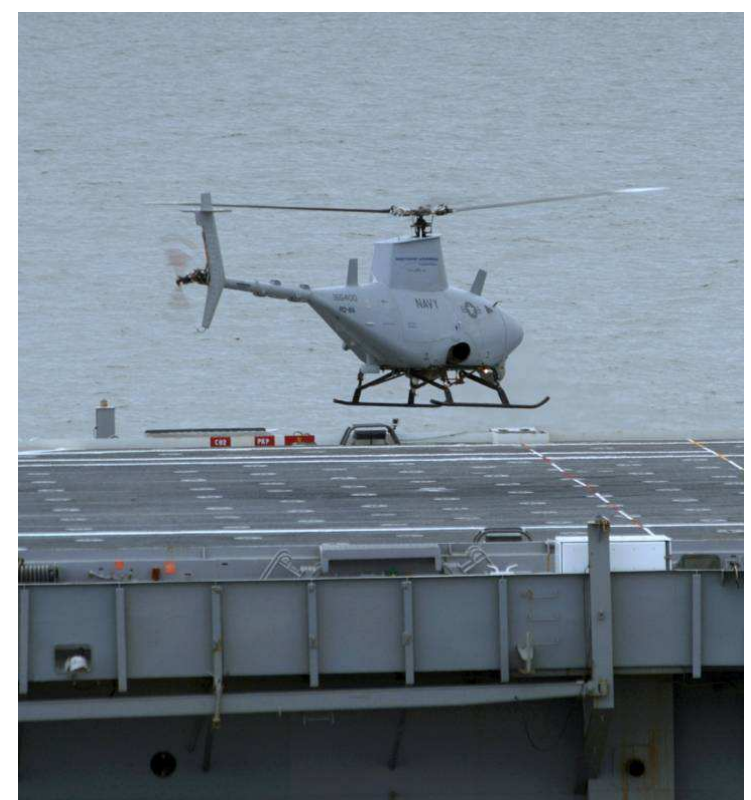

Fig. 5: Fire scout Vertical Takeoff and Landing Tactical Unmanned Aerial Vehicle (VTUAV). Courtesy of U.S. Navy; photo by Kurt Lengfield

In January 2006, an RQ-8A shield landed aboard the Nashville Amphibious Shipping while landing on the Maryland Coast near the Patuxent River. It marked the first time that an unmanned helicopter landed autonomously on a US-operated ship without a pilot commissioned in Nashville, which tested $27 \mathrm{~km} / \mathrm{h}$ in this test. Then $24 \mathrm{MQ}-$ 8B will be deployed on naval vessels in early 2014 . Firefighting research contributes significantly to the roles of the LCS anti-submarine warfare, surface warfare and mine warfare. The modular nature of the ship is complemented by the modular tasks of the modular mission of the shield. Due to changes in the LCS development program, Marina performed the Scout fire operational assessment (OpEval) aboard the McInerney frigate. On December 10, 2008, the fire shield began for the first time aboard McInerney, in the port for operational controls and ship integration tests. Marina performed the technical assessment of McInerney Fire Detector at the end of 2008 and the operational assessment in mid-2009. Shield's role was to reach its initial operating capacity shortly after the evaluation. In May 2009, fire tests were carried out, tests carried out in the ship's areas of motion and the expansion and landing of wind envelopes, including the use of the network and the harpoon system. During the five days of testing, the ship/aircraft team compiled 19 flight hours over 12 flights, of which 54 landings, of which 37 in the NATO standard network. In September 2009, Marina announced the first MQ-8B move aboard McInerney. On 3 April 2010, McInerney's MQ-8 detected a cocaine and smuggling boat in the Eastern Pacific, allowing the ship to confiscate 60 kilos of cocaine and hold more traffickers (Fig. 6). 


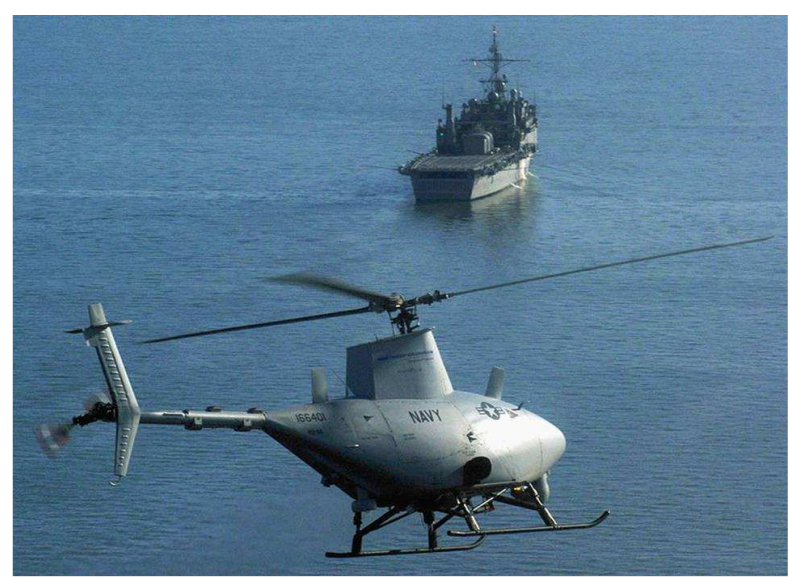

Fig. 6: An RQ-8A prepares for the first autonomous landing aboard the USS Nashville (LPD-13) during sea trials, 2006

It should also be mentioned that on August 2, 2010, an MQ-8 did not respond to orders during the tests and entered the restricted airspace around Washington, D.C.

\section{Discussion}

In May 2011, three MQ-8 operations were carried out in an Information, Surveillance and Reconnaissance (ISR) operation in northern Afghanistan.

During the 2011 military intervention in Libya, several fire shields were operated aboard Halyburton by HSL-42 scads as part of the Unified Protector operation. On June 21, 2011, an MQ-8 from Halyburton was hit by pro-Gaddafi forces during a reconnaissance mission. It was the first failure in real-world operations, but it was an unmanned aircraft anyway.

US vessels created the MQ-8B shortly after two aircraft collapsed within a week. In the first incident, a fire detector collapsed off the coast of Africa on March 30 after the Simpson frigate did not land after a surveillance mission. On April 6, 2012, another fire detector collapsed in Afghanistan. An investigation into the collapse in Afghanistan showed that the cause was a flawed navigation system. The cause of the collapse near Simpson remained less clear, so more tough maintenance procedures were implemented to prevent the planes from moving on a mission. Since May, the fire inspector has returned to Afghanistan and resumed initial operations to combat ISR piracy by August.

On December 1, 2012, Klakring returned from a fivemonth operation to support anti-piracy operations for the US Command of Africa. The fourth station held more than $500 \mathrm{~h}$ of flight and regularly maintained $12 \mathrm{~h}$ of service per station to ensure continued support. A fire detector has set up a one-day record, providing ISR coverage for a 24-h period in September 2012 with over 10 flights. On March 31, 2013, an MQ-8B led by Robert
G. Bradley ended his 600-h flight during the 5th Scout Fire group. It was for the first time a helicopter squadron (HSC-22) deployed with a fire detector; previous installations were carried out by the Maritim Strike helicopter community. Between 2006 and 2013, the scout flew over $8,000 \mathrm{~h}$, over half of the world's operations. In June 2013, the Helicopter Marine Corps (HSM) 46, Det. 9 exceeded the monthly record of the MQ-8B Marine Flight aboard Samuel B. Roberts, flying for 333 flight hours during the sixth helicopter.

In August 2013, the MQ-8B exceeded 5000 flight hours in Afghanistan. In 28 months, fire scientists accumulated 5,084 h, providing critical oversight for US and Allied forces. Combined with testing and six deployments at sea, the helicopter has over 10,000 flight hours supporting the naval and land forces. At the end of 2013, the fire inspector completed the deployment mission in Afghanistan and was sent back to the US. The MQ-8B will continue to be deployed on naval frigates and will be integrated into seagoing ships. Marina also commissioned AN/ZPY-4 Telephonics radar to expand surveillance capabilities. Twelve radars, including the three spare parts, will be delivered by December 2014 . The Navy will buy a total of $96 \mathrm{MQ}-8 \mathrm{~B} / \mathrm{C}$ researchers.

Between April 25 and May 16, 2014, USS Freedom (LCS-1) led the concept of future operations (CONOPS) for unmanned and unmanned helicopters aboard naval vessels.

The operations were performed by the MH-60R crew with the MQ-8B crew without personnel. The demonstration included an MH-60R and an MQ-8B flying with the installed Battle Surface (SUW) package designed to provide fleet protection against small boats and asymmetric threats.

The tests were to demonstrate unmanned and unmanned helicopter capabilities before being installed together, launched on November 14, 2014.

On December 5, 2014, an MQ-8B ship broke out for the first time in the US for a Coast Cutter, USCGC Bertholf (WMSL-750). The scout was controlled from a command station at Bertholf. The Coast Guard intends to use demonstration results to inform decisions about the purchase of an UAS to enhance persistent maritime surveillance capabilities while reducing operational costs.

On October 16, 2016, two MQ-8B fire detection systems were installed in Singapore, which had for the first time AN / ZPY-4 (V) radar, 200 surface search and flight avoidance objects.

\section{Conclusion}

Flying taxis, dozens of autonomous cars, the City Airbus project plunges us into the greatest Science Fiction movies. By taking up the challenge of working and imagining the means of transport that will be used by the people of the cities of the future, Airbus is trying to get a 
head start, even if, without a doubt, its competitors also have plans in the boxes.

Because if nowadays to be able to circulate in the large conglomerations is a permanent challenge, what will it be in the years to come? The problem of transport in the big cities is growing and will continue to be so since by 2030 $60 \%$ of the world's population will live in big cities, which represents a growth of $10 \%$ compared to today.

City Airbus, the flying and autonomous taxi of Airbus could be a part of the solution to the mobility problem that future planners will have to solve.

\section{Acknowledgement}

We acknowledge and thank Mr Taher M. AbuLebdeh, Associate Prof at North Carolina A and T State Univesity, United States and Mr Muftah H. El-Naas PhD MCIC FICCE QAFCO Chair Professor in Chemical Process Engineering Gas Processing Center College of Engineering Qatar University and Ms Shweta Agarwala, Senior Research Scientist at Singapore Center for 3D Printing Nanyang Technological University Singapore for their suggestions and comments.

\section{Author's Contributions}

All the authors contributed equally to prepare, develop and carry out this manuscript.

\section{Ethics}

This article is original and contains unpublished material. The corresponding author confirms that all of the other authors have read and approved the manuscript and no ethical issues involved.

\section{References}

Aversa, R., R.V.V. Petrescu, A. Apicella and F.I.T. Petrescu, 2017a. Nano-diamond hybrid materials for structural biomedical application. Am. J. Biochem. Biotechnol., 13: 34-41. DOI: 10.3844/ajbbsp.2017.34.41

Aversa, R., R.V. Petrescu, B. Akash, R.B. Bucinell and J.M. Corchado et al., 2017b. Kinematics and forces to a new model forging manipulator. Am. J. Applied Sci., 14: 60-80. DOI: 10.3844/ajassp.2017.60.80

Aversa, R., R.V. Petrescu, A. Apicella, I.T.F. Petrescu and J.K. Calautit et al., 2017c. Something about the $\mathrm{V}$ engines design. Am. J. Applied Sci., 14: 34-52. DOI: 10.3844/ajassp.2017.34.52

Aversa, R., D. Parcesepe, R.V.V. Petrescu, F. Berto and G. Chen et al., 2017d. Process ability of bulk metallic glasses. Am. J. Applied Sci., 14: 294-301. DOI: 10.3844/ajassp.2017.294.301
Aversa, R., R.V.V. Petrescu, B. Akash, R.B. Bucinell and J.M. Corchado et al., 2017e. Something about the balancing of thermal motors. Am. J. Eng. Applied Sci., 10: 200-217. DOI: 10.3844/ajeassp.2017.200.217

Aversa, R., F.I.T. Petrescu, R.V. Petrescu and A. Apicella, 2016a. Biomimetic FEA bone modeling for customized hybrid biological prostheses development. Am. J. Applied Sci., 13: 1060-1067. DOI: 10.3844/ajassp.2016.1060.1067

Aversa, R., D. Parcesepe, R.V. Petrescu, G. Chen and F.I.T. Petrescu et al., 2016b. Glassy amorphous metal injection molded induced morphological defects. Am. J. Applied Sci., 13: 1476-1482. DOI: 10.3844/ajassp.2016.1476.1482

Aversa, R., R.V. Petrescu, F.I.T. Petrescu and A. Apicella, 2016c. Smart-factory: Optimization and process control of composite centrifuged pipes. Am. J. Applied Sci., 13: 1330-1341.

DOI: 10.3844 /ajassp.2016.1330.1341

Aversa, R., F. Tamburrino, R.V. Petrescu, F.I.T. Petrescu and M. Artur et al., 2016d. Biomechanically inspired shape memory effect machines driven by muscle like acting NiTi alloys. Am. J. Applied Sci., 13: 1264-1271. DOI: 10.3844/ajassp.2016.1264.1271

Aversa, R., E.M. Buzea, R.V. Petrescu, A. Apicella and M. Neacsa et al., 2016e. Present a mechatronic system having able to determine the concentration of carotenoids. Am. J. Eng. Applied Sci., 9: 1106-1111. DOI: 10.3844/ajeassp.2016.1106.1111

Aversa, R., R.V. Petrescu, R. Sorrentino, F.I.T. Petrescu and A. Apicella, 2016f. Hybrid ceramo-polymeric nanocomposite for biomimetic scaffolds design and preparation. Am. J. Eng. Applied Sci., 9: 1096-1105. DOI: 10.3844/ajeassp.2016.1096.1105

Aversa, R., V. Perrotta, R.V. Petrescu, C. Misiano and F.I.T. Petrescu et al., 2016g. From structural colors to super-hydrophobicity and achromatic transparent protective coatings: Ion plating plasma assisted $\mathrm{TiO} 2$ and $\mathrm{SiO} 2$ Nano-film deposition. Am. J. Eng. Applied Sci., 9: 1037-1045. DOI: 10.3844/ajeassp.2016.1037.1045

Aversa, R., R.V. Petrescu, F.I.T. Petrescu and A. Apicella, 2016h. Biomimetic and evolutionary design driven innovation in sustainable products development. Am. J. Eng. Applied Sci., 9: 1027-1036. DOI: 10.3844/ajeassp.2016.1027.1036

Aversa, R., R.V. Petrescu, A. Apicella and F.I.T. Petrescu, 2016i. Mitochondria are naturally micro robots-a review. Am. J. Eng. Applied Sci., 9: 991-1002. DOI: 10.3844/ajeassp.2016.991.1002

Aversa, R., R.V. Petrescu, A. Apicella and F.I.T. Petrescu, 2016j. We are addicted to vitamins $\mathrm{C}$ and E-A review. Am. J. Eng. Applied Sci., 9: 1003-1018. DOI: 10.3844 /ajeassp.2016.1003.1018 
Aversa, R., R.V. Petrescu, A. Apicella and F.I.T. Petrescu, 2016k. Physiologic human fluids and swelling behavior of hydrophilic biocompatible hybrid ceramo-polymeric materials. Am. J. Eng. Applied Sci., 9: 962-972. DOI: 10.3844/ajeassp.2016.962.972

Aversa, R., R.V. Petrescu, A. Apicella and F.I.T. Petrescu, 20161. One can slow down the aging through antioxidants. Am. J. Eng. Applied Sci., 9: 1112-1126. DOI: 10.3844/ajeassp.2016.1112.1126

Aversa, R., R.V. Petrescu, A. Apicella and F.I.T. Petrescu, 2016m. About homeopathy or «Similia similibus curentur $\gg$. Am. J. Eng. Applied Sci., 9: 1164-1172. DOI: 10.3844/ajeassp.2016.1164.1172

Aversa, R., R.V. Petrescu, A. Apicella and F.I.T. Petrescu, 2016n. The basic elements of life's. Am. J. Eng. Applied Sci., 9: 1189-1197. DOI: 10.3844/ajeassp.2016.1189.1197

Aversa, R., F.I.T. Petrescu, R.V. Petrescu and A. Apicella, 2016o. Flexible stem trabecular prostheses. Am. J. Eng. Applied Sci., 9: 1213-1221. DOI: 10.3844/ajeassp.2016.1213.1221

Mirsayar, M.M., V.A. Joneidi, R.V.V. Petrescu, F.I.T. Petrescu and F. Berto, 2017. Extended MTSN criterion for fracture analysis of soda lime glass. Eng. Fracture Mechanics, 178: 50-59. DOI: 10.1016/j.engfracmech.2017.04.018

Northrop Grumman Fire Scout performs first autonomous naval landing of a UAV", US Navy. http://www.navy.mil/submit/display.asp?story_id=2 2038

Northrop Grumman MQ-8 Fire Scout, From Wikipedia. The free encyclopedia.

https://en.wikipedia.org/wiki/Northrop_Grumman MQ-8_Fire_Scout

Petrescu, F.I. and R.V. Petrescu, 2011. Memories About Flight. 1st Edn., CreateSpace, pp: 652.
Petrescu, F.I. and R.V. Petrescu, 2012b. New Aircraft II. 1st Edn., Books on Demand, pp: 138.

Petrescu, R.V. and FIT. Petrescu, 2012a. Northrop. Books on Demand. ISBN-13: 978-3848209323, pp: 142.

Petrescu, F.I.T., 2009. New aircraft. Proceedings of the 3rd International Conference on Computational Mechanics, Oct. 29-30, Brasov, Romania.

Petrescu, R.V. and F.I. Petrescu, 2013a. Lockheed Martin. 1st Edn., CreateSpace, pp: 114.

Petrescu, R.V. and F.I. Petrescu, 2013b. Northrop. 1st Edn., CreateSpace, pp: 96.

Petrescu, R.V. and F.I. Petrescu, 2013c. The Aviation History or New Aircraft I Color. 1st Edn., CreateSpace, pp: 292.

\section{Source of Figures:}

Fig. 1:

http://www.robots-et-compagnie.com/wpcontent/uploads/2016/11/ville-du-futur-5-730x356.jpg

Fig. 2:

http://www.robots-et-compagnie.com/wp-

content/uploads/2016/11/City-Airbus-voiture-volanteautonome-2-300x183.jpg

Fig. 3:

http://www.robots-et-compagnie.com/wpcontent/uploads/2016/11/City-Airbus-voiture-volanteautonome-1-300x192.jpg

Fig. 4:

https://en.wikipedia.org/wiki/Northrop_Grumman_MQFig. 5: 8_Fire_Scout\#/media/File:MQ-8B_Fire_Scout.jpeg

http://www.navy.mil/view_imagex.asp?id=31351\&t=1

Fig. 6:

https://en.wikipedia.org/wiki/Northrop_Grumman_MQ-

8_Fire_Scout\#/media/File:Fire_Scout_unmanned_helicopt er_crop.jpg 